\title{
Health Care Network: Maternal perception regarding the quality of care to children with microcephaly
}

\author{
Rede de Atenção à Saúde: Percepção materna quanto à qualidade de atendimento de \\ crianças com microcefalia
}

Red de Atención a la Salud: Percepción materna en cuanto a la calidad de atención de niños con microcefalia

Daniel Batista Conceição dos Santos ${ }^{1}($ (1)

Elaine Ferreira da Silva ${ }^{1}$ (iD)

Sonia Oliveira Lima ${ }^{2}$ (1)

Francisco Prado Reis ${ }^{2}$ (D)

Cristiane da Costa Cunha Oliveira ${ }^{2}$ (1D)

1. Universidade Tiradentes, Programa de

Pós-graduação em Saúde e Ambiente.

Aracaju, SE, Brasil.

2. Universidade Tiradentes, Departamento de Enfermagem. Aracaju, SE, Brasil.
Corresponding author:

Daniel Batista Conceição dos Santos.

E-mail: daniel_bdcs@hotmail.com

Submitted on 11/13/2018.

Accepted on 06/13/2019.

DOI: 10.1590/2177-9465-EAN-2018-0335

\begin{abstract}
Objective: To identify the perception of primary caregivers on the quality of the Health Care Network of children with microcephaly related to congenital infection. Methods: A cross-sectional study carried out from October 2017 to April 2018. Results: The 105 participants assessed the health of their children as reasonable (56.1\%). The level of care which got the highest percentage - 57 $(54.3 \%)$ - of participants' dissatisfaction was of Primary Health Care $(p=0.0216)$. Most of the specialties of secondary health care services were classified as poor/very poor, regarding the quality of the consultation at the secondary level $(p<0.05)$. For the majority - $61(58 \%)$ - of the mothers, regarding this level of attention, the items waiting time and appointment scheduling were evaluated as excellent/good $(p<0.05)$. Conclusion and implications for practice: There is dissatisfaction among mothers considering the quality of services provided by the health care network for children with microcephaly, mainly in primary care. There was easiness in the access to Secondary Care, and little use of Tertiary Care services. It is urgent to elaborate policies that better disseminate humanization and facilitate the accessibility to multiprofessional care for those children.
\end{abstract}

Keywords: Microcephaly; Health Care; Child health; Integrality in Health, Caregivers.

\section{Resumo}

Objetivo: Identificar a percepção de cuidadores principais sobre a qualidade da Rede de Atenção à Saúde de crianças com microcefalia relacionada à infecção congênita. Métodos: Estudo de corte transversal realizado no período de outubro de 2017 a abril de 2018. Resultados: As 105 participantes avaliaram a saúde de seus filhos como razoável (56,1\%). O nível de atenção que obteve o maior percentual - 57(54,3\%) - de insatisfação das participantes foi o da Atenção Primária à Saúde ( $\mathrm{p}=0,0216)$. A maioria das especialidades da Atenção Secundária à Saúde foi classificada como ruim/muito ruim, quanto à qualidade da consulta no nível secundário $(p<0,05)$. Para a maioria - $61(58 \%)$ - das mães, quanto a esse nível de atenção, os itens tempo de espera e agendamento de consulta foram avaliados como excelente/bom $(p<0,05)$. Conclusão e implicações para a prática: Existe insatisfação das mães com a qualidade dos serviços prestados pela Rede de Atenção à Saúde da criança com microcefalia, principalmente na Atenção Primária. Houve facilidade no acesso à Atenção Secundária, e pequena utilização dos serviços da Atenção Terciária. É urgente a elaboração de políticas que melhor difundam a humanização e facilitem a acessibilidade ao atendimento multiprofissional para essas crianças.

Palavras-chave: Microcefalia; Atenção à Saúde; Saúde da criança; Integralidade em Saúde, Cuidadores.

\section{Resumen}

Objetivo: Identificar la percepción de cuidadores principales sobre la calidad de la Red de Atención a la Salud de niños con microcefalia relacionada con infección congénita. Métodos: Investigación de corte transversal realizada entre octubre 2017 y abril de 2018. Resultados: Las 105 participantes evaluaron la salud de sus hijos como razonable (56,1\%). El nivel de atención que obtuvo el mayor porcentaje de insatisfacción - 57(54,3\%) - fue en la Atención Primaria ( $p=0,0216)$. La mayoría de las especialidades de la Atención Secundaria fueron clasificadas como mala/muy mala, sobre la calidad de la consulta en el nivel secundario $(p<0,05)$. Para la mayoría - $61(58 \%)$ - de las madres, en cuanto a ese nivel de atención, los ítems tiempo de espera y programación de consulta fueron evaluados como excelente/bueno. Conclusión e implicaciones para la práctica: Hubo insatisfacción de las madres con la calidad de servicios prestados por la Red de Atención a la Salud del niño con microcefalia principalmente en la Atención Primaria. Hubo facilidad de acceso a la Atención Secundaria, y poca utilización de los servicios de la Atención Terciaria. Es urgente la elaboración de políticas que mejor difundan la humanización y faciliten la accesibilidad a la atención multiprofesional para estos niños.

Palabras clave: Microcefalia; Atención a la Salud; Salud del niño; Integralidad en Salud, Cuidadores. 


\section{INTRODUCTION}

The Brazilian Unified Health System (UHS) is considered one of the largest and most complex health systems in the world due to its universal, free and full access character. The complexity of its constitution is mainly related to the continental dimensions of the country, to the diversities of the regional contexts, with different health needs of the population and to the rapid demographic and epidemiological transition. ${ }^{1}$ Allied to this, there is a triple burden of diseases that is defined as the "unresolved agenda of infectious and deficiencies diseases, an important burden of external causes and a strong hegemonic presence of chronic conditions". 2-18 This problem is aggravated by the fragmentation of the system with a focus on the confronting of acute conditions. ${ }^{2}$

The users of the UHS face difficulties in the universality and integrality of access to public health services. ${ }^{3}$ Thus, there is great dissatisfaction among the population in relation to the services provided by the UHS, which demonstrates its inefficiency and lack of resolution towards the health needs of users. ${ }^{4}$ In order to overcome the challenges and advance the qualification of health care, it was necessary to innovate in the process of organizing the UHS, redirecting its actions and services in networks. ${ }^{5}$

The Health Care Networks ( $\mathrm{HCN})$ are polyarchic organizations of sets of services implemented by the Ministry of Health $(\mathrm{MH})$ as a strategy to restructure the system in order to solve its fragmentation. $\mathrm{HCN}$ are organized in increasing degrees of complexity and should be coordinated by Primary Health Care (PHC), providing continuous and comprehensive assistance to the population through expanded access to primary care, free treatment of various communicable diseases, and expansion of surveillance actions for the prevention and control of epidemics. ${ }^{5-2}$

In Brazil, during the years 2015 and 2016, the Zika virus epidemic led to an increase in the prevalence of cases of microcephaly associated with congenital infection. In the American continent, Brazil had the highest number of confirmed cases, and the Northeast region was the most affected, with the states of Pernambuco and Bahia concentrating the highest percentage of confirmed cases. ${ }^{6,7}$

Microcephaly is a Congenital Malformation (CM) in which the brain does not develop properly, being characterized by a cephalic perimeter lower than expected for the age and sex, depending on its etiology, may be associated with structural malformations of the brain as impaired neuronal proliferation or cortical progenitor cell deaths. ${ }^{8,9}$ Congenital infections are notably deleterious to fetal organogenesis. Rubella viruses, human immunodeficiency virus and cytomegalovirus, Treponema pallidum, Toxoplasma gondi and now more recently the relationship with Zika virus are associated with $\mathrm{CM} .{ }^{10,11}$
Most cases of microcephaly are accompanied by motor and cognitive changes that vary according to the degree of brain involvement. In addition to delays in neuropsychomotor development, other limitations may be present such as difficulty in speech, vision, memory skills, arthrogryposis and seizures. . $^{7,9,12}$

The $\mathrm{MH}$, through emergency measures, has sought to provide support for the $\mathrm{HCN}$ organization of the child with microcephaly in order to improve the integral care of these children. From this, managers and health professionals can acquire subsidies for the identification of priority actions for children with microcephaly. The UHS has made efforts to meet the needs of the child and his/her family through the implementation of surveillance protocols and health care, as well as the training of its professionals for the purpose of detection, early notification and follow-up of confirmed cases. ${ }^{13}$

Due to his/her complex clinical fragility, the child with microcephaly will need an integral, lifelong care that provides a life with quality for the child and his/her caregivers. Considering the investments made by the $\mathrm{MH}$ for the structuring of the $\mathrm{HCN}$ of the child with microcephaly and the importance of evaluating the quality of the services offered by the network in the process of developing actions that will lead to greater efficiency and improvements in access, it is necessary to identify the perception of caregivers on the quality of the Health Care Network of children with microcephaly related to congenital infection.

\section{METHOD}

Cross-sectional, descriptive study of quantitative approach performed from October 2017 to April 2018. Data were collected at a High Risk Maternity, Center for Medical Specialties of Children and Adolescents and a School of Clinical Dentistry reference in the care of children with microcephaly.

For the study population, the following criteria were used: primary caregivers older than 16 years of age, children with microcephaly with a brain abnormality diagnosed by imaging, and by a specific and conclusive laboratory test for Zika and STORCH (syphilis, toxoplasmosis, rubella, cytomegalovirus or herpes simplex). Caregivers whose children were not considered cases of microcephaly were excluded.

According to epidemiological surveillance, in the period from November $5^{\text {th }}, 2015$ to March $6^{\text {th }}, 2017$, the state of Sergipe presented the confirmation of 129 cases of children with microcephaly. ${ }^{14}$ It was decided that the study population would include the census of all cases. In March 2018, there were already registered in the health services 136 cases of children affected by microcephaly, of these 31 were excluded due to the lack of confirmation of the diagnosis for microcephaly related to the congenital syndrome. The population of this study was 105 primary caregivers of children with microcephaly. 
An instrument developed by the team of researchers based on the validated Primary Attention Assessment questionnaire ${ }^{15}$ was used, which consists of three 3-point Likert-type scales (ranging from very good to very poor, excellent to very poor; unsatisfied to satisfied). The quality variables for the three levels of child health care were: the need for specialized services, the quality of health professionals' care, waiting time for care, good structural conditions. The variables were measured by simple frequency analysis. The interviews were conducted in the order in which caregivers arrived to be attended by the multiprofessional team. The interviews were carried out by handing out the letter of presentation of the research to the users or guardians, as well as reading and signing of the Term of Free and Informed Consent.

The data were evaluated through descriptive and bivariate statistical analyses using the Chi-square test $\left(\chi^{2}\right)$ to verify the differences in the distribution of the perception of the main caregivers on the health of the child with microcephaly by health microregion, quality of health care of the child by microregion of health, the quality of the health care of the child with the satisfaction of the caregivers concerning $\mathrm{HCN}$. A statistical significance level of $5 \%(p<0.05)$ was used. The ethical approval of the study was obtained by the Research Ethics Committee of Tiradentes University, under protocol No. 2,227,026.

\section{RESULTS}

A total of 105 caregivers who had ties of mothers of children with microcephaly related to congenital infection participated in the study. The participants assessed their children's health as reasonable $(56.1 \%)$, followed by very good (37.1\%), with no significant differences between health microregions $(p=0.982)$ (Table 1).

The results presented in Table 2 suggest users' dissatisfaction with health services at the three levels of care. Regarding the quality of services offered by Primary Health Care (PHC), there was a significant difference when distributed by microregions of health. For $54.2 \%$ of the users, the dissatisfaction with the quality of the services provided by $\mathrm{PHC}$ prevails. The majority of the mothers residing in the Centro Sul (87.5\%), and Alto Sertão $(75 \%)$ stated that they were dissatisfied with the services provided by this level of care $(p=0.0216)$.

The analysis of the quality variables of the services provided by the medical and nursing specialties when associated with satisfaction with the PHC's quality showed that the majority of respondents were satisfied $(p<0.05)$. When questioned about the quality of the consultation, the duration of the consultation and the waiting time between the scheduling and the actual consultation, the majority of the mothers interviewed evaluated as excellent $\operatorname{good}(\mathrm{p}<0.05)$ and stated that the needs of their child are attended by the consultation of these professionals $(p<0.05)$ (Table 3$)$.

Regarding the variables related to the dental specialty, it can be seen that most of the users do not use this service, when associated with the satisfaction with $\mathrm{PHC}$ 's quality there was a significant difference for all variables $(p<0.001)$.

Table 4 shows the association between the variables of the $\mathrm{HCN}$ quality towards the child with microcephaly and the satisfaction with the quality of Secondary Health Care (SHC) services. It was observed that there was an association for most of the variables, and the participants who stated that they were satisfied with the services at this level of attention and stated that the waiting time between the scheduling of the consultation to the specialties of the referral center and its effectiveness was excellent/good $(p<0.005)$. Regarding the quality of the consultation for these specialties, the majority affirmed that it is poor/very poor and declared dissatisfaction with the services of the SHC $(p<0.001)$. Pediatric dentistry was evaluated as poor or very poor for $25.0 \%$ of the main caregivers, although the majority (59\%) stated that they did not use this service.

Mothers generally did not use the services of Tertiary Health Care (THC) in all variables for this level, 49 (46.6\%) of the interviewees reported not using these services. Of the services used, the quality of the consultations was assessed by specialties with the respective percentage level: pediatric neurosurgeon $(90.1 \%)$, orthopedic surgeon $(99.6 \%)$, gastroenterologist $(90.4 \%)$, and pediatric surgery $(87.9 \%)$.

Table 1. Perception of the mothers of children with microcephaly regarding the health of their child. Sergipe, 2018.

\begin{tabular}{|c|c|c|c|c|c|c|c|c|c|c|}
\hline \multirow{2}{*}{$\begin{array}{l}\text { Perception of } \\
\text { Your Child's } \\
\text { Health }\end{array}$} & \multicolumn{7}{|c|}{ Microregion of Health } & \multirow[b]{2}{*}{ Total } & \multirow[b]{2}{*}{$* \chi^{2}$} & \multirow[b]{2}{*}{ p* } \\
\hline & $\begin{array}{c}\text { Alto } \\
\text { Sertão }\end{array}$ & $\begin{array}{l}\text { Baixo São } \\
\text { Francisco }\end{array}$ & $\begin{array}{l}\text { Agreste } \\
\text { Central }\end{array}$ & $\begin{array}{c}\text { Centro } \\
\text { Sul }\end{array}$ & $\begin{array}{c}\text { Leste } \\
\text { Sergipano }\end{array}$ & $\begin{array}{l}\text { Grande } \\
\text { Aracaju }\end{array}$ & $\begin{array}{c}\text { Sul } \\
\text { Sergipano }\end{array}$ & & & \\
\hline Very good/good & $3(37.5)$ & $1(33.3)$ & $7(41.2)$ & $4(50)$ & $4(36.4)$ & $17(37.8)$ & $3(23.1)$ & $39(37.1)$ & 4.076 & 0.982 \\
\hline Reasonable & $4(50)$ & $2(66.7)$ & 9 (52.9) & $3(37.5)$ & $7(63.6)$ & $25(55.6)$ & $9(69.2)$ & $59(56.1)$ & & \\
\hline Total & $8(7.61)$ & $3(2.85)$ & $17(16.1)$ & $8(7.61)$ & $11(10.4)$ & $45(42.8)$ & $13(12.3)$ & $105(100)$ & & \\
\hline
\end{tabular}

* Chi-square test $\left(\chi^{2}\right)$ 
Table 2. Perception of the mothers regarding the satisfaction with the quality of the HCN services. Sergipe, 2018.

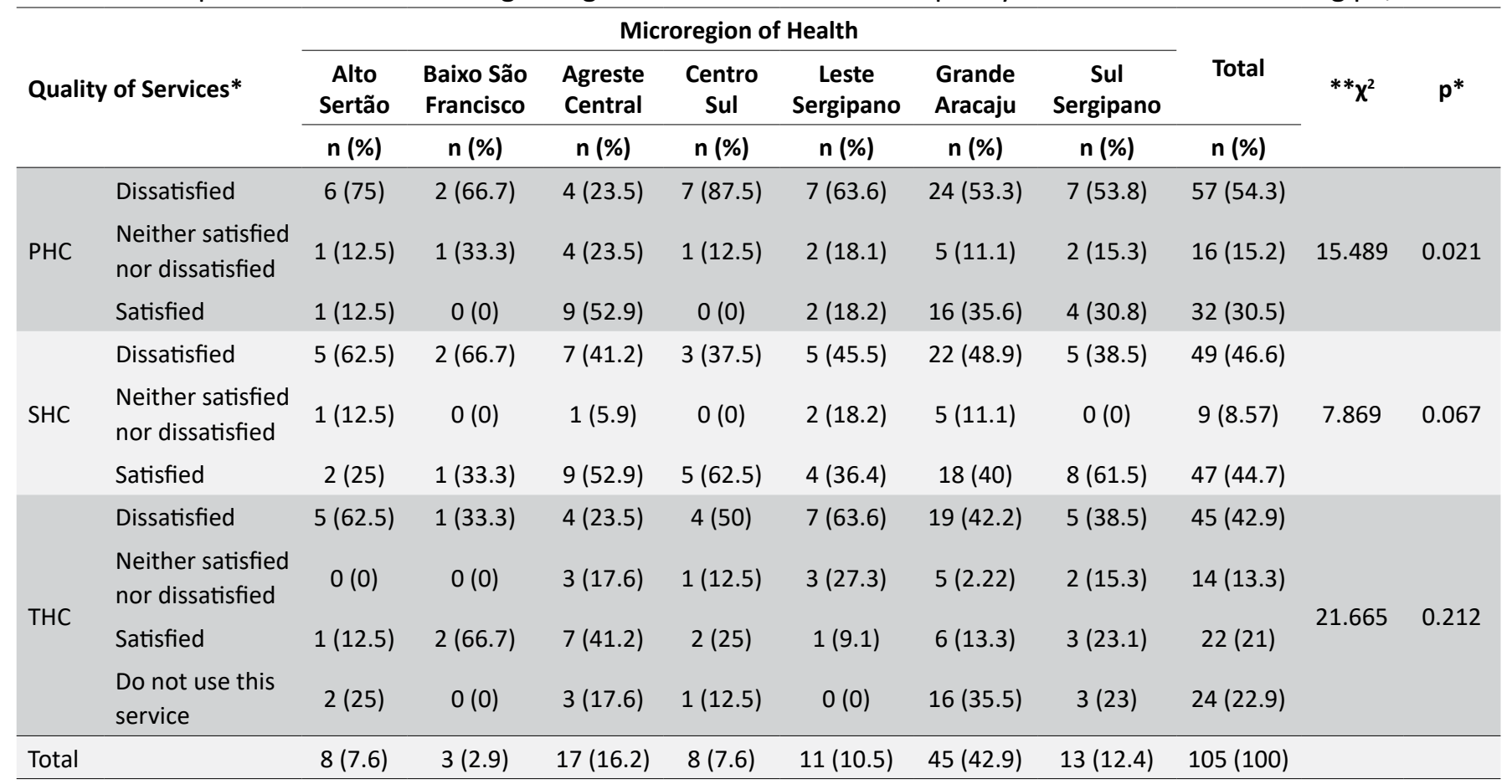

* Primary Health Care (PHC), Secondary Health Care (SHC), Tertiary Health Care (THC); ${ }^{* *}$ Chi-square test $\left(\chi^{2}\right)$.

Table 3. Perception of mothers regarding satisfaction with the quality of PHC's services. Sergipe, 2018.

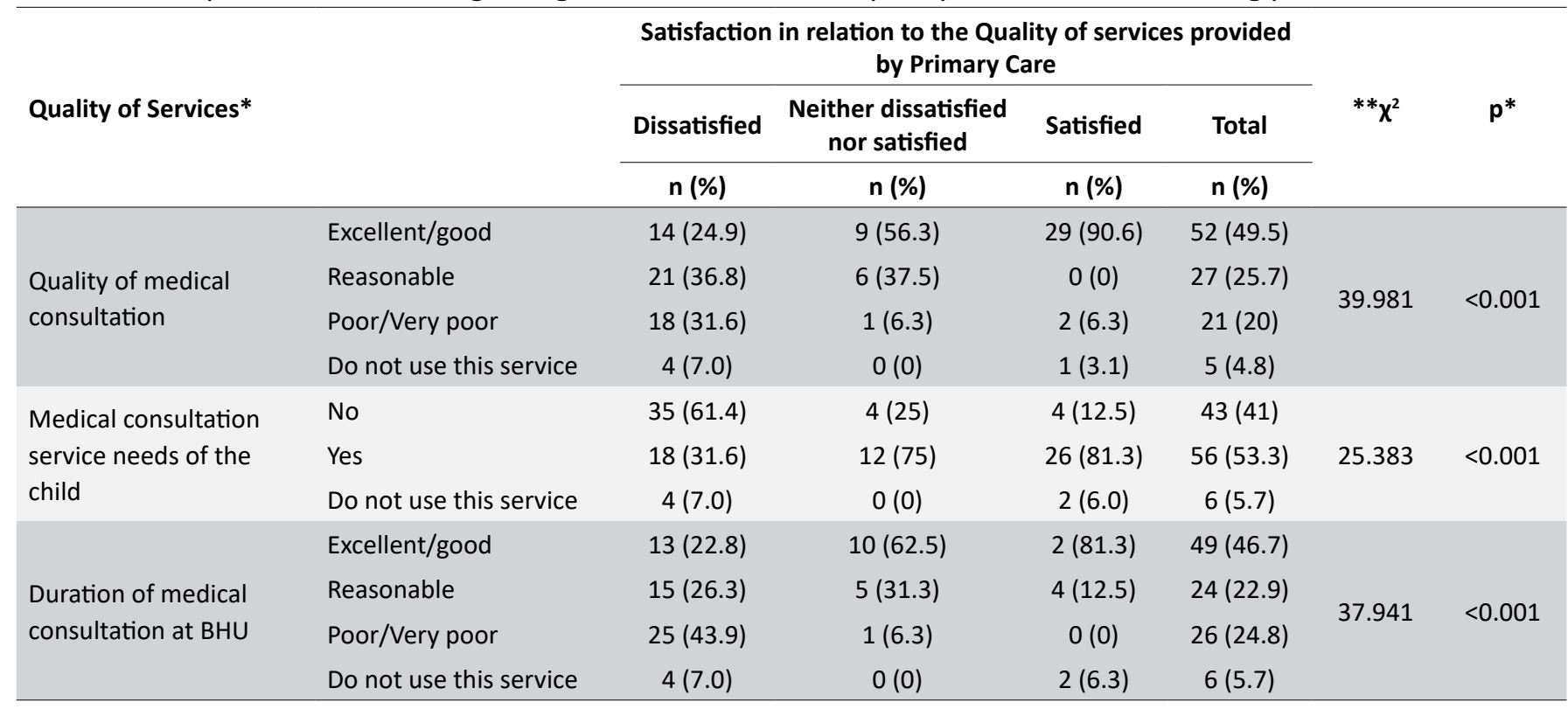


Continuation Table 3.

\begin{tabular}{|c|c|c|c|c|c|c|c|}
\hline \multirow{3}{*}{ Quality of Services* } & & \multicolumn{4}{|c|}{$\begin{array}{l}\text { Satisfaction in relation to the Quality of services provided } \\
\text { by Primary Care }\end{array}$} & \multirow{3}{*}{${ }^{* *} \chi^{2}$} & \multirow{3}{*}{$\mathbf{p}^{*}$} \\
\hline & & \multirow{2}{*}{$\begin{array}{c}\text { Dissatisfied } \\
\mathrm{n}(\%)\end{array}$} & \multirow{2}{*}{$\begin{array}{c}\begin{array}{c}\text { Neither dissatisfied } \\
\text { nor satisfied }\end{array} \\
\mathrm{n}(\%)\end{array}$} & \multirow{2}{*}{$\begin{array}{c}\text { Satisfied } \\
\text { n (\%) }\end{array}$} & \multirow{2}{*}{$\begin{array}{l}\text { Total } \\
\text { n (\%) }\end{array}$} & & \\
\hline & & & & & & & \\
\hline \multirow{4}{*}{$\begin{array}{l}\text { Waiting time between } \\
\text { the appointment of the } \\
\text { medical consultation } \\
\text { and its effectiveness }\end{array}$} & Excellent/good & 11 (19.3) & $8(50)$ & $21(65.6)$ & $40(38.1)$ & \multirow{4}{*}{28.458} & \multirow{4}{*}{$<0.001$} \\
\hline & Reasonable & $15(26.3)$ & $7(43.8)$ & $5(15.6)$ & $27(25.7)$ & & \\
\hline & Poor/Very poor & $27(47.4)$ & $1(6.3)$ & $4(12.5)$ & $32(30.5)$ & & \\
\hline & Do not use this service & $4(7.0)$ & $0(0)$ & $2(6.3)$ & $6(5.7)$ & & \\
\hline \multirow{4}{*}{$\begin{array}{l}\text { Quality of nursing con- } \\
\text { sultation }\end{array}$} & Excellent/good & $22(38.6)$ & $12(75)$ & $25(78.1)$ & $69(56.2)$ & \multirow{4}{*}{18.000} & \multirow{4}{*}{0.006} \\
\hline & Reasonable & 18 (31.6) & $1(6.3)$ & $5(15.6)$ & 24 (22.9) & & \\
\hline & Poor/Very poor & $11(19.3)$ & $1(6.3)$ & $1(3.1)$ & $13(12.4)$ & & \\
\hline & Do not use this service & $6(10.5)$ & $2(12.5)$ & $1(3.1)$ & $9(8.6)$ & & \\
\hline \multirow{3}{*}{$\begin{array}{l}\text { Attendance of the } \\
\text { nursing consultation to } \\
\text { the needs of the child }\end{array}$} & No & $17(29.8)$ & $4(25)$ & $1(3.1)$ & $22(21.0)$ & \multirow{3}{*}{13.893} & \multirow{3}{*}{0.008} \\
\hline & Yes & 34 (59.6) & $9(56.3)$ & $30(93.8)$ & $73(69.5)$ & & \\
\hline & Do not use this service & $6(10.5)$ & $3(18.7)$ & $1(3.1)$ & $10(9.5)$ & & \\
\hline \multirow{4}{*}{$\begin{array}{l}\text { Duration of the Nursing } \\
\text { consultation at } \mathrm{BHU}\end{array}$} & Excellent/good & $19(33.3)$ & $8(50)$ & $26(81.3)$ & $53(50.5)$ & \multirow{4}{*}{21.164} & \multirow{4}{*}{0.002} \\
\hline & Reasonable & $23(40.4)$ & $4(25)$ & $4(12.5)$ & $31(29.5)$ & & \\
\hline & Poor/Very poor & $9(15.8)$ & $1(6.3)$ & $1(3.1)$ & $11(10.5)$ & & \\
\hline & Do not use this service & $6(10.5)$ & $3(18.8)$ & $1(3.1)$ & $10(9.5)$ & & \\
\hline \multirow{4}{*}{$\begin{array}{l}\text { Waiting time between } \\
\text { scheduling of the } \\
\text { nursing consultation and } \\
\text { its effectiveness }\end{array}$} & Excellent/good & $22(38.6)$ & $10(62.5)$ & $26(81.3)$ & $58(55.2)$ & \multirow{4}{*}{18.849} & \multirow{4}{*}{0.004} \\
\hline & Reasonable & $18(31.6)$ & $2(12.5)$ & $4(12.5)$ & 24 (22.9) & & \\
\hline & Poor/Very poor & $11(19.3)$ & $1(6.3)$ & $1(3.1)$ & $13(12.4)$ & & \\
\hline & Do not use this service* & $6(10.5)$ & $3(18.8)$ & $1(3.1)$ & $10(9.5)$ & & \\
\hline \multirow{4}{*}{$\begin{array}{l}\text { Quality of the dental } \\
\text { consultation }\end{array}$} & Excellent/good & $7(12.3)$ & $1(6.3)$ & $12(37.5)$ & 20 (19) & \multirow{4}{*}{24.761} & \multirow{4}{*}{$<0.001$} \\
\hline & Reasonable & $2(3.5)$ & $2(12.5)$ & $3(9.4)$ & $7(6.7)$ & & \\
\hline & Poor/Very poor & 25 (43.9) & $3(18.8)$ & $1(3.1)$ & $29(27.6)$ & & \\
\hline & Do not use this service & $23(40.4)$ & $10(62.5)$ & $16(50)$ & $49(46.7)$ & & \\
\hline Attendance of the & No & 29 (50.9) & $3(18.8)$ & $5(15.6)$ & $37(35.2)$ & & \\
\hline dental consultation to & Yes & $5(8.8)$ & $2(12.5)$ & $11(34.4)$ & $18(17.1)$ & 18.929 & $<0.001$ \\
\hline & Do not use this service & $23(40.4)$ & $11(68.8)$ & $16(50)$ & $50(47.6)$ & & \\
\hline & Excellent/good & $6(10.5)$ & $0(0)$ & $9(28.1)$ & $15(14.3)$ & & \\
\hline Duration of the dental & Reasonable & $2(3.5)$ & $3(18.8)$ & $5(15.6)$ & $10(9.5)$ & 29825 & $<0001$ \\
\hline consultation & Poor/Very poor & $22(38,6)$ & $1(6.3)$ & $0(0)$ & 23 (21.9) & & \\
\hline & Do not use this service & $27(47.4)$ & $12(75)$ & $18(56.3)$ & $57(54.3)$ & & \\
\hline Waiting time between & Excellent/good & $5(8.8)$ & $0(0)$ & $10(31.3)$ & $15(14.3)$ & & \\
\hline scheduling of the dental & Reasonable & $5(8.8)$ & $2(12.5)$ & $4(12.5)$ & $11(10.5)$ & 26014 & $<0001$ \\
\hline consultation and its & Poor/Very poor & $21(36.8)$ & $1(6.3)$ & $1(3.1)$ & $23(21.9)$ & & \\
\hline effectiveness & Do not use this service & $26(45.6)$ & $13(81.3)$ & $17(53.1)$ & $56(53.3)$ & & \\
\hline Total & & $57(54.3)$ & $16(15.2)$ & $32(30.5)$ & $105(100)$ & & \\
\hline
\end{tabular}

* Primary Health Care (PHC); ${ }^{* *}$ Chi-square test $\left(\chi^{2}\right)$. 
Table 4. Perception of the mothers regarding the satisfaction with the quality of the SSA services. Sergipe, 2018.

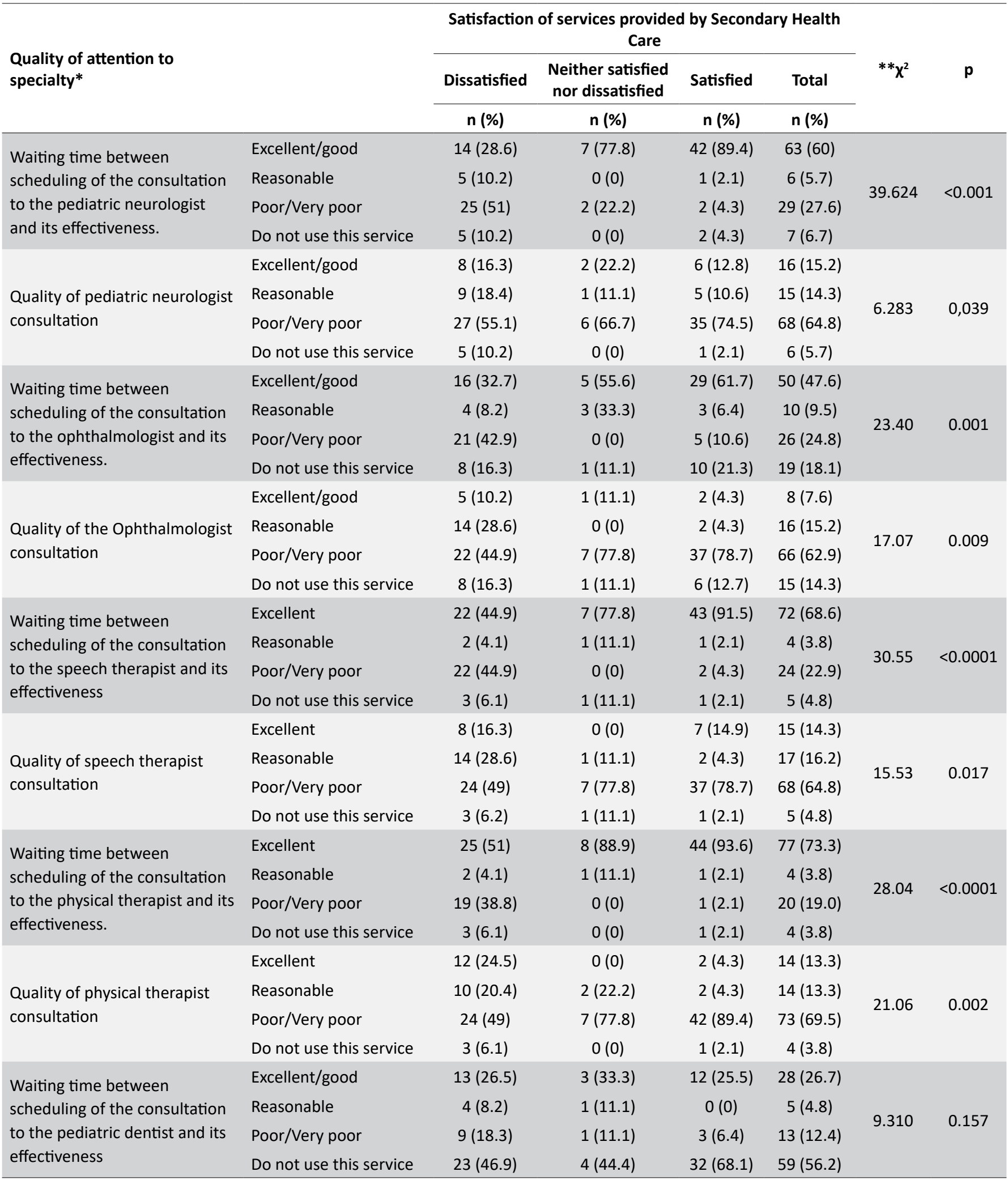




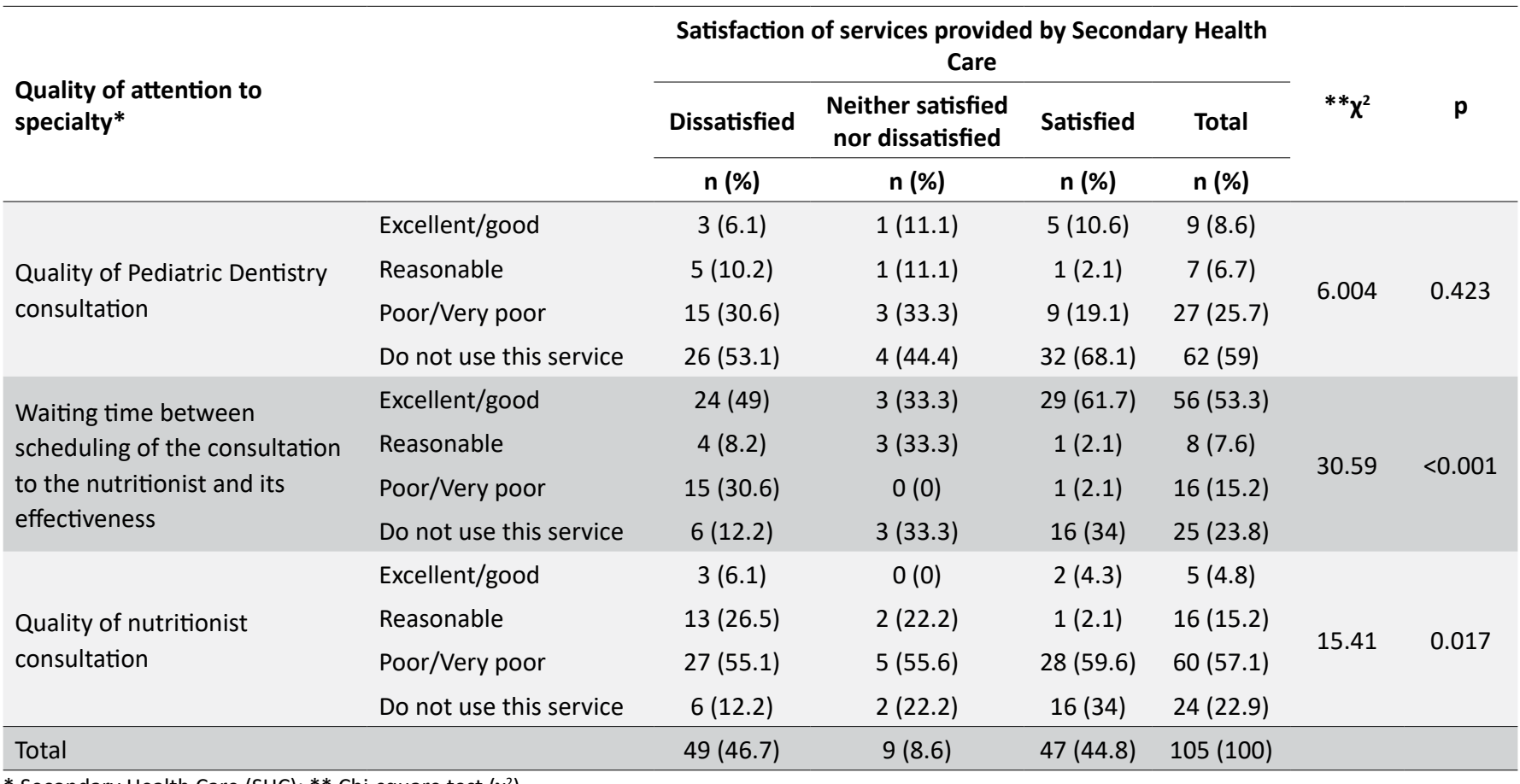

* Secondary Health Care (SHC); ${ }^{* *}$ Chi-square test $\left(\chi^{2}\right)$.

\section{DISCUSSION}

It is noted that in the perception of the mothers of children with microcephaly related to congenital infection, the services offered by the $\mathrm{HCN}$ were classified as unsatisfactory for all levels of attention. In the distribution by health microregions, $\mathrm{PHC}$ had the highest percentage of dissatisfaction when compared to other levels of care $(p=0.0216)$. The effectiveness of the HCN is a major challenge for the UHS, the system's fragmentation, underfinancing and lack of effective public policies are some of the factors that have led to the poor operationalization of the network. ${ }^{2}$ Thus, it is necessary to create new strategies that provide the integration of the system in a coordinated way to provide integral, continuous and quality assistance to children with microcephaly.

This study corroborated a study carried out in the Federal District that evaluated the integral care of healthy children in PHC and found levels of dissatisfaction in several essential attributes for the complete care. ${ }^{16}$ However, studies conducted in São Paulo and Rio de Janeiro with healthy children indicated that the mothers attributed good results to the evaluation of the attributes for PHC in the services provided by the Family Health Teams (FHT). ${ }^{17,18} \mathrm{It}$ is noticed that there is controversy regarding satisfaction in the care of children in PHC, a fact probably dependent on quality of service provided to the user. It is therefore important that there is a periodic evaluation of the quality of the services provided based on indicators of self-evaluation and external evaluation to optimize the service to the public in need..$^{19}$
In Sergipe, when stratified by microregions of health, the worst evaluations were concentrated outside the Grande Aracaju metropolitan region. This result is in agreement with studies carried out with caregivers of children living in a quilombola community in Minas Gerais and in the city of Teresópolis, in Rio de Janeiro, who reported difficulties in the conditions of access to services, due to a greater dispersion of the Family Health Units (FHU). ${ }^{20,21}$ This points out to the need to increase the universality of care through spreading to cities of the interior and the decentralization of health services.

The strengthening of $\mathrm{PHC}$ is essential for the formation of the $\mathrm{HCN}$, since its role as a care coordinator is fundamental to guarantee the continuity of care of users in other levels of care. ${ }^{2,5}$ Regarding accessibility, difficulties in obtaining consultations to specialties were observed in this study in both PHC and SHC. Accessibility enables users to reach services according to their needs, and access is related to the timely use of services, minimizing difficulties and expanding the facilities to obtain resources. ${ }^{22}$ Faced with this, it is important to guarantee health equity for children with microcephaly through the creation of intersectoral actions and public policies that allow breaking the access barriers guaranteeing accessibility and longitudinality of care.

The perception of the mothers was related to the attention provided by the secondary and tertiary levels, which was evidenced by the interviewees' dissatisfaction about the quality of the services in these levels of attention of the HCN. These results 
corroborate a study carried out in Vitória da Conquista, where caregivers of asthmatic children evaluated how poor/very poor the treatment applied to these children were. These authors drew attention to the complexity of situations in the clinical situation of children with chronic diseases and emphasized the need for follow-up by specialists in referral centers. ${ }^{21}$ In this way, the integrality of the child with microcephaly should be monitored at all three levels health care.

When asked about their child's perception of health, most interviewees said it was reasonable. Studies have already demonstrated a neuropsychomotor development impairment in the majority of children with microcephaly related to congenital infection. The systemic disorders associated with this congenital syndrome such as epilepsy, optic nerve atrophy, musculoskeletal disorders and otoacoustic emission lead to a severe impairment of health. ${ }^{6-8,12}$ Thus, the child with microcephaly becomes extremely dependent on specialized attention.

Significant associations were found in the present study between the satisfaction of the interviewees regarding the quality of the $\mathrm{HCN}$ and the quality of the services offered by the multiprofessional team. For PHC, the medical and nursing specialties obtained good evaluations in all areas, except for the waiting time for the medical consultation, in which $30.4 \%$ of the participants stated that it was poor/very poor. These data are in agreement with a study carried out with users of caregivers of children in Minas Gerais, where they reported high levels of satisfaction related to access by these health professionals. However, the huge waiting time, the difficulties in scheduling consultations and inefficient referrals become barriers that impede care. ${ }^{23}$ It is possible that it is necessary to improve the accessibility of children with microcephaly to consultation with health professionals, in addition to prioritizing care by clinical criterion.

There was a considerable percentage of participants in this study who reported not using the FHU dental services $(p<0.001)$. Regarding the quality of the consultation, the mothers of children with microcephaly who evaluated this item stated (43.8\%) that it was poor/very poor, and assessed PHC as dissatisfied. The difficulty of creating and linking the oral health team and the FHU users is due to the lack of resoluteness of these teams in identifying health problems, the delay in consultation schedules and failure in referring to specialized services..$^{24}$ Care and follow-up concerning the oral health of a child with special needs are essential for the maintenance of integral health. ${ }^{25}$ This fact reinforces the need to implement public policies that improve the resoluteness and the access to dental care for the child with microcephaly.

As for SHC, it can be seen that part of the interviewed mothers who said they were satisfied with the services offered, evaluated as excellent/good the waiting time in the consultation and as poor/very poor in relation to the quality of the consultation. The results of this study are in agreement with a study that evaluated the continuity and longitudinality of the care of the child and adolescent with chronic illness which revealed the lack of articulation among professionals and service of reference and counterreference. ${ }^{26}$ Humanized care and user satisfaction are directly related to the reception received by health professionals during the consultation. The attention given during care, the respect for the patient and the duration of the consultation are factors that influence this process. ${ }^{27}$ In this way, the training of professionals and health workers should be intensified, favoring the commitment to the humanization of care.

In this study, for the pediatric dentistry specialty a high percentage of participants stated that they did not use this service. This may be related to a failure in the HCN's communication and the lack of a consolidated reference service. A study with children with special needs carried out at a school in the city of Patos, in the state of Paraiba, reported the importance of pediatric dentistry in the integral care of the child for the promotion of oral health. ${ }^{25} \mathrm{It}$ is necessary to create specific health programs for children with microcephaly focusing on the recognition of changes in oral health conditions.

Regarding the waiting time between the scheduling of the consultation for the various specialties associated with the evaluation of the services provided by the SHC, the majority of the interviewees evaluated as excellent/good for all variables $(p<0.001)$, except for the pediatric dentist due to the high number of participants who declared that they did not use this service. Studies that focus on the perception of caregivers about the quality of care provided to children have demonstrated a long waiting time for care by health professionals. ${ }^{23-25,26}$ Thus, it is necessary to think more and more about the elimination of barriers to access creating public policies and specific programs that facilitate the accessibility of children with microcephaly and their caregivers to health services.

Brazil has evolved in the last decades in the implementation of public policies that guarantee the integrality of the health care in the maternal-infant scope. The increase in universal coverage coupled with the reduction of regional and socioeconomic inequalities has a direct impact on the reduction of maternal and child mortality. ${ }^{28}$ The structuring of the $\mathrm{HCN}$ of children with microcephaly is a challenge for the UHS since there is no specific treatment for this $\mathrm{CM}$ being necessary supporting actions for their growth and development. This monitoring should be performed by a multiprofessional team with specialties that address the motor, respiratory and neurological disorders of these children. ${ }^{13}$ To this end, it is necessary for the UHS to develop specific care lines for children with microcephaly, including family training in care and treatment. 
SHC plays an extremely important role in the $\mathrm{HCN}$ as regards to the resoluteness and comprehensiveness of care, providing specialized services for specific needs. ${ }^{29} \mathrm{~A}$ child with special needs will need a structured network that provides ease of access and quality care. ${ }^{21,25}$ The child with microcephaly fits in this context because of the various disorders associated with the congenital syndrome, so he/she needs resolute and integral assistance.

In the present study, it was identified that most of the mothers interviewed reported not using THC services. This fact is due to the needs of children with microcephaly being concentrated in the second level of attention, that although present difficulties in the attendance they obtain resoluteness through the specialties. The care of the child with microcephaly in the HCN must follow an integral and continuous line at all levels of the network coordinated by the PHC. ${ }^{2,5-26}$ Thus, the need to strengthen the $\mathrm{HCN}$ is demonstrated, through the creation of public policies that improve the communication between levels of attention, promoting integral care of the child with microcephaly.

\section{CONCLUSION AND IMPLICATIONS FOR PRACTICE}

The analysis of the mothers' perception showed a high degree of dissatisfaction with the services offered by the $\mathrm{HCN}$ of the child with microcephaly. The study also showed that the level of PHC presented a higher degree of dissatisfaction in relation to the other levels. Regarding the evaluation of the quality of the consultation of the PHC's professionals, the nursing received the best evaluations. As for the services provided, it was easy to access to SHC, but the care of most professionals was evaluated as poor/very poor, while THC was little used.

The findings also indicated the need for greater investments in the structuring and integration of services offered by the HCN, as well as the strengthening of PHC. The coordination of care by the PHC has been identified as an essential attribute for the organization of health systems, being considered as the preferred entry point in the UHS. To ensure a better quality of health care for children with microcephaly and to improve the satisfaction of their caregiver mothers, it is essential to create policies and programs that promote health equity by facilitating the access of these children to health services. In addition, it is also essential to invest in the qualification of the multiprofessional team focused on efficient and humanized service.

The results of this study contribute to the debate about the structuring of the $\mathrm{HCN}$ of the child with microcephaly, but present limitations with regard to the design of the study that does not allow interferences on the directionality of the associations. In addition, predictors of mothers' satisfaction/dissatisfaction regarding the quality of care for children with microcephaly should be evaluated in future studies in order to enable a more detailed investigation using regression models and adjusting co-variables to dependent variables.

\section{REFERENCES}

1. Paim J, Travassos C, Almeida C, Bahia L, Macinko J.The Brazilian health system: history, advances, and challenges. Lancet [Internet]. 2011 may [cited 2018 dec 25]; 377(9779):1778-1797. Available from: https://www. thelancet.com/journals/lancet/article/PIIS0140-6736(11)60054-8/fulltext DOI: https://doi.org/10.1016/S0140-6736(11)60054-8

2. Mendes EV. Organização Pan-Americana da Saúde. Conselho Nacional de Secretários de Saúde. As redes de atenção à saúde. $2^{a}$ ed. Brasília (DF): Organização Pan-Americana da Saúde; 2011. Available from: https://www.paho.org/bra/index.php?option=com docman\&view=download\&category slug=servicos-saude095\&alias=1402-as-redes-atencao-a-saude-2a-edicao-2\&ltemid=965

3. Martins LFV, Meneghim MCM, Martins LC, Pereira AC. Avaliação da qualidade nos serviços públicos de saúde com base na percepção dos usuários e dos profissionais. RFO [Internet]. 2014 may/aug; [cited 2018 oct 10]; 19(2):151-158. Available from: http://seer.upf.br/index.php/rfo/ article/view/3566/2988 DOI: http://dx.doi.org/10.5335/rfo.v19i2.3566

4. Pinheiro $\mathrm{R}$, Martins $\mathrm{PH}$, organizadores. Avaliação em saúde na perspectiva do usuário: abordagem multicêntrica. Rio de Janeiro (RJ) CEPESC; 2009. Available from: https://lappis.org.br/site/wp-content/ uploads/2017/12/Avalia\%C3\%A7\%C3\%A3o-em-Sa\%C3\%BAde-naPerspectiva-do-usu\%C3\%A1rio-abordagem-multic\%C3\%AAntrica.pd

5. Arruda C, Lopes SGR, Koerich MHAL, Winck DR, Meirelles BHS, Mello ALF. Redes de atenção à saúde sob a luz da teoria da complexidade. Esc Anna Nery [Internet]. 2015 mar; [cited 2018 dec 25]; 19(1):169-173. Available from http://www.scielo.br/scielo.php?script=sci_arttext\&pid $=$ S1414-81452015000100169

6. Oliveira WK, França GVA, Carmo EH, Duncan BB, Kuchenbecker RS Schmidt MI. Infection-related microcephaly after the 2015 and 2016 Zika virus outbreaks in Brazil: a surveillance-based analysis. Lance [Internet]. 2017 aug; [cited 2018 dec 25]; 390(10097):861-870. Available from: https://www.ncbi.nlm.nih.gov/pubmed/28647172 DOI: https://doi. org/10.1016/S0140-6736(17)31368-5

7. França GV, Schuler-Faccini L, Oliveira WK, Henriques CM, Carmo $\mathrm{EH}$, Pedi VD, et al. Congenital Zika virus syndrome in Brazil: a case series of the first 1501 livebirths with complete investigation. Lancet [Internet]. 2016 aug; [cited 2018 dec 25]; 388(10047):891-897. Available from: https://www.thelancet.com/journals/lancet/article/ PIIS0140-6736(16)30902-3/fulltext DOI: http://dx.doi.org/10.1016/ S0140-6736(16)30902-3

8. Ashwal S, Michelson D, Plawner L, Dobyns WB. Practice parameter Evaluation of the child with microcephaly (an evidence-based review): report of the Quality Standards Subcommittee of the American Academy of Neurology and the Practice Committee of the Child Neurology Society. Neurology [Internet]. 2009 sep; [cited 2018 sep 22]; 73(11):887-97. Available from: http://www.pubmedcentral.nih.gov/articlerender.fcgi?a rtid=2744281\&tool=pmcentrez\&rendertype=abstract

9. Nunes ML, Carlini CR, Marinowic D, Neto FK, Fiori HH, Scotta MC, et al. Microcephaly and Zika virus: a clinical and epidemiological analysis of the current outbreak in Brazil. J Pediatr [Internet]. 2016 may/jun; [cited 2018 dec 25]; 92(3):230-40. Available from: https://www.ncbi.nlm.nih gov/pubmed/27049675 DOI:https://doi.org/10.1016/j.jped.2016.02.009

10. Mlakar J, Korva M, Tul N, Popovic M, Poljsak-Prijatelj M, Mraz J, et al Zika virus associated with microcephaly. N Engl J Med [Internet]. 2016 mar; [cited 2018 dec 25]; 374(10):951-8. Available from: https://www. ncbi.nlm.nih.gov/pubmed/26862926 DOI: https://doi.org/10.1056/ NEJMoa1600651

11. Wen Z, Song H, Ming GL. How does Zika virus cause microcephaly? Genes Dev [Internet]. 2017 may; [cited 2018 dec 25]; 31(9):849-861. Available from: https://www.ncbi.nlm.nih.gov/pubmed/28566536 DOI https://doi.org/10.1101/gad.298216.117

12. Moore CA, Staples JE, Dobyns WB, Pessoa A, Ventura CV, Fonseca $\mathrm{EB}$, et al. Characterizing the Pattern of Anomalies in Congenital Zika Syndrome for Pediatric Clinicians. JAMA Pediatr [Internet]. 2017 mar; [cited 2018 dec 26]; 171(3):288-295. Available from: https://www. ncbi.nlm.nih.gov/pubmed/27812690 DOI: http://doi.org/10.1001/ jamapediatrics.2016.3982 
13. Ministério da Saúde (BR). Secretaria de Vigilância em Saúde. Boletim Epidemiológico. Monitoramento integrado de alterações no crescimento e desenvolvimento relacionados à infecção pelo vírus Zika e outras etiologias infecciosas, da Semana Epidemiológica 45/2015 até a Semana Epidemiológica 02/2017. Brasília (DF): Ministério da Saúde;2017. Available from: $h$ ttp://portalarquivos.saude.gov.br/images/ pdf/2017/fevereiro/27/2017_003.pdf

14. Sergipe. Secretaria de Estado da Saúde. Informe epidemiológico ano III no 12 - até a semana epidemiológica 27 (01/07 a 07/07/2018). Atualização da situação epidemiológica da dengue, chikungunya, Zika e dos casos de microcefalia em Sergipe. Aracaju: Secretaria de Estado da Saúde; 2017; [access in 2018 oct 20]. Available from: https://www. saude.se.gov.br/wp-content/uploads/2018/07/Inform_Seman_12_Micro_Chik_Dengue_Zika_Semana.27-2018.pdf

15. Ministério da Saúde (BR). Secretaria de Atenção em Saúde. Departamento de Atenção Básica. Manual do instrumento de avaliação da atenção primária à saúde - Primary Care Assessment Tool PCATool - Brasil. Brasília (DF): Ministério da Saúde;2010. Available from: http:// dab.saude.gov.br/portaldab/biblioteca.php?conteudo=publicacoes/ manual_instrumento_avaliacao

16. Araújo RL, Mendonça AVM, Sousa MF. Percepção dos usuários e profissionais de saúde no Distrito Federal: os atributos da atenção primária. Saúde Debate [Internet]. 2015 apr/jun.; [cited 2018 sep 24]; 39(105):387-399. Available from: http://www.scielo.br/scielo. php?pid=S0103-11042015000200387\&script=sci_abstract\&tlng=pt DOI: http://doi:10.1590/0103-110420151050002007

17. Furtado MC, Braz JC, Pina JC, Mello DF, Lima RAGL. A avaliação da atenção à saúde de crianças com menores de um ano de idade na Atenção Primária. Rev Latino-Am Enfermagem [Internet]. 2013 mar/apr; [cited 2018 oct 01];21 (2):554-561. Available from: http://www.scielo.br/scielo.php?pid=S0104-11692013000200554\&script=sci_arttext\&tlng=pt DOI: http://dx.doi.org/10.1590/S0104-11692013000200012

18. Pinto LF, Harzheim E, Hauser L, D'Avila OP, Goncalves MR, Travassos $P$, et al. A qualidade da Atenção Primária à Saúde na Rocinha - Rio de Janeiro, Brasil, na perspectiva dos cuidadores de crianças e dos usuários adultos. Ciênc Saúde Coletiva [Internet]. 2017 mar; [cited 2018 sep 25]; 22(3):771-781. Available from: http://www.scielo.br/scielo. php?pid=S1413-81232017002300771\&script=sci_abstract\&tlng=pt DOI: http://dx.doi.org/10.1590/1413-81232017223.33132016

19. Pinto HA, Sousa ANA, Ferla AA. O Programa Nacional de Melhoria do Acesso e da Qualidade da Atenção Básica: várias faces de uma política inovadora. Saúde Debate [Internet]. 2014 oct; [cited 2018 dec 27]; 38(spe):358-372. Available from: http://www.scielo.br/pdf/ sdeb/v38nspe/0103-1104-sdeb-38-spe-0358.pdf DOI: http://dx.doi. org/10.5935/0103-1104.2014S027

20. Ribeiro JM, Siqueira SAV, Pinto FS. Avaliação da atenção à saúde da criança (0-5 anos) no PSF de Teresópolis (RJ) segundo a percepção dos usuários. Ciênc Saúde Coletiva [Internet]. 2010 mar; [cited 2018 oct 10]; 15(2):514-527. Available from: http://www.scielo.br/scielo. php?pid=S1413-81232010000200028\&script=sci_abstract\&tlng=pt DOI: http://dx.doi.org/10.1590/S1413-81232010000200028
21. Miranda VC, Reis LA, Morais KCS, Ferreira JB, Alves TC. Percepção da mãe ou cuidador de crianças asmáticas sobre os resultados do tratamento. Saúde Debate [Internet]. 2016 jul/sep; [cited 2018 aug 21]; 40(110):195-207. Available from: https://www.scielosp.org/article/ssm/ content/raw/?resource_ssm_path=/media/assets/sdeb/v40n110/01031104-sdeb-40-110-0195.pdf DOI: https://doi.org/10.1590/01031104201611015

22. Starfield B, Shi L, Macinko J. Contribution of primary care to health systems and health. Milbank Q [Internet]. 2005; [cited $2018 \mathrm{dec}$ 28]; 83(3):457-502. Available from: https://www.ncbi.nlm.nih.gov/ pubmed/16202000

23. Modes PSSA, Gaíva MAM. Satisfação das usuárias quanto à atenção prestada à criança pela Rede Básica de Saúde. Esc Anna Nery [Internet]. 2013 jul/sep; [cited 2018 oct 12]; 17(3):455-465. Available from: http://www.redalyc.org/articulo.oa?id=127728368008

24. Munkevi MSG, Pelicioni MCF. Saúde bucal na Estratégia Saúde da Família no município de São Paulo: perspectiva do usuário. Rev Bras Crescimento Desenvolv Hum [Internet]. 2010; [cited 2018 oct 20]; 20(3):787-97. Available from: http://pepsic.bvsalud.org/scielo. php?script=sci_arttext\&pid=S0104-12822010000300014

25. Queiroz FS, Rodrigues MMLF, Cordeiro Junior GA, Oliveira AB Oliveira JD, Almeida ER. Avaliação das condições de saúde bucal de Portadores de Necessidades Especiais. Rev Odontol UNESP [Internet]. 2014 dec; [cited 2018 sep 25]; 43(6):396-401. Available from: http:// www.scielo.br/pdf/rounesp/v43n6/1807-2577-rounesp-43-06-0396. pdf DOI: http://dx.doi.org/10.1590/1807-2577.1013

26. Nobrega VM, Reichert APS, Viera CS, Collet N. Longitudinalidade e continuidade do cuidado à criança e ao adolescente com doença crônica. Esc Anna Nery [Internet]. 2015 dec; [cited 2018 oct 10]; 19(4):656-663. Available from: http://www.scielo.br/scielo. php?pid=S1414-81452015000400656\&script=sci_abstract\&tlng=pt

27. Marques AS, Freitas DA, Leão CDA, Oliveira SKM, Pereira MM, Caldeira AP. Atenção Primária e saúde materno-infantil: a percepção de cuidadores em uma comunidade rural quilombola. Ciênc Saúde Coletiva [Internet]. 2014 feb; [cited 2018 oct 01]; 19(2):365371. Available from: http://www.scielo.br/scielo.php?pid=S141381232014000200365\&script=sci_abstract DOI: http://dx.doi. org/10.1590/1413-81232014192.02992013

28. Victora CG, Aquino EML, Leal MC, Monteiro CA, Barros FC, Szwarcwald CL. Maternal and child health in Brazil: progress and challenges. Lancet [Internet]. 2011 may; [cited 2018 dec 27]; 377(9780):1863-1876. Available from: https://www.thelancet.com/journals/lancet/article/ PIIS0140-6736(11)60138-4/fulltext DOI: https://doi.org/10.1016/ S0140-6736(11)60138-4

29. Erdmann AL, Andrade SR, Mello ALSF, Drago LC. A atenção secundária em saúde: melhores práticas na rede de serviços. Rev Latino-Am Enfermagem [Internet]. 2013 jan/fev; [cited 2018 oct 22]; 21(spe):[aprox.8 telas]. Available from: http://www.scielo.br/pdf/rlae/ v21nspe/pt_17.pdf 